\title{
Origin and Production of Silver in Early Medieval Poland
}

\author{
Ewelina A. Miśta-Jakubowska ${ }^{a}$, Renata Czech Błońska ${ }^{b}$, Władysław \\ Duczko $^{c}$, Aneta M. Gójska ${ }^{d}$, Paweł Kalbarczyk ${ }^{e}$, Andrzej Turos', \\ Grzegorz Żabiński ${ }^{g}$ and Maciej Widawski ${ }^{h}$
}

\begin{abstract}
Modern archaeology makes use of analytical methods in order to answer questions about deposit and technological provenience of artefacts. This paper discusses selected and the most interesting, results obtained during the completion of a research project which focuses on silver from the Ioth and IIth centuries in Poland. In total, 200 silver artefacts known from Polish hoards (found in Kalisz-Dobrzec, Nowa Obra, Wolsztyn District, Zalesie, Olsztyn District, Słuszków and Jastrzębniki, Kalisz District, Kalisz-Rajsków and Stojkowo, Kołobrzeg District and Naruszewo, Płońsk District) were studied. A micro-invasion LA-ICP-MS (Laser Inductively Coupled Plasma Mass Spectrometry) was used for determinining lead isotope ratios in silver. The data obtained were evaluated using statistical methods which allowed reliable isotopic ratios in inhomogeneous alloy to be obtained. In order to study the provenance of silver, the obtained lead isotope ratios in the artefacts were compared with those of silver deposits. The use of SEM-EDX allowed the tracing of morphological changes and the measurement of quantitative elemental composition of coins, raw silver and jewellery according to technological traits.
\end{abstract}

KEY-WORDS: Silver in medieval Poland, SEM-EDX, LA-ICP-MS, lead isotope ratio analyses, statistical models.

a National Centre for Nuclear Research, Andrzeja Sołtana 2, 05-400 Otwock, Poland, e-mail: Ewelina. Mista@ncbj.gov.pl; ORCID: 0000-0002-0053-87II

${ }^{b}$ Institute of Archaeology and Ethnology Polish Academy of Science, Aleja Solidarności I05, O0-I40 Warsaw, Poland, e-mail: renata-czech@wp.pl ORCID: oooo-ooo2-7043-7246

c Pultusk Academy of Humanities, Daszyńskiego 17, 06-Ioo Pułtusk, Poland, e-mail: wladyslawduczko@ gmail.com ORCID: o0oo-oooI-9037-8944

$d$ National Centre for Nuclear Research, Andrzeja Sołtana 2, 05-400 Otwock, Poland, e-mail: Aneta. Gojska@ncbj.gov.pl ORCID: 0000-0002-1550-2180

e Institute of Nuclear Chemistry and Technology, Dorodna 16, 03-195 Warsaw, Poland, e-mail: pawelkalbarczyk@02.pl ORCID: 0000-0003-4264-3410

$f$ Łukasiewicz Research Network - Institute of Electronic Materials Technology, Wólczyńska I33, OI-9I9 Warsaw, Poland, e-mail: Andrzej.Turos@itme.edu.pl ORCID: oooo-0o02-4II3-5089

g Jan Długosz University, Jerzego Waszyngtona 4/8, 42-20o Częstochowa, Poland, e-mail: g.zabinski@ gmail.com ORCID: 0000-0003-309I-I035

h State Archaeological Museum in Warsaw, Długa 52, 00-04I Warsaw, Poland, e-mail: mac_56@wp.pl ORCID: 0000-0002-3544-3253 
242 Ewelina A. Miśta-Jakubowska, Renata Czech Btońska, Wtadystaw Duczko, Aneta M. Gójska ...

\section{INTRODUCTION}

During three years (20I4-20I7) a project was carried out that focused on attempts at defining the provenance of silver in Polish coins and West Slav jewellery discovered in deposits - hoards from Ioth and IIth century Poland. The material from selected Polish hoards underwent analytic studies by elemental and lead isotopic ratio determination. This paper discusses results obtained for 60 coins, 26 jewellery artefacts and 25 pieces of raw silver. The coin assemblage contained Saxon deniers of Otto and Adelaide (Io items), cross deniers (3 items) from the Słuszków hoard and Polish coins - Palatine Sieciech's deniers (Io items from the Słuszków hoard), different varieties of cross deniers (27 items from the Jastrzębniki and Słuszków hoards). Furthermore, dirhams (ıo items) from the Ašsšas, Ma'din and Andaraba mints from the Nowa Obra and Zalesie hoards were studied. The jewellery finds come from the Rajsków, Słuszków and Stojkowo hoards. Raw silver "cakes" were part of the Kalisz-Dobrzec and Jastrzębniki hoards, while bars were present in the Naruszewo hoard.

The use of non-invasive scanning electron microscopy with X-ray microanalysis (SEM-EDX) provided information about the elemental composition and structural characteristics in relation to technological aspects of the finds. However, the main goal of this project was to reveal the origin of silver which is connected with the study of lead isotope ratios as "fingerprints" of the artefacts and silver ores. The micro-invasive Laser Ablation Inductively Coupled Plasma Mass Spectrometry (LA-ICP-MS; e.g. Dziunikowski 1998; Gale and Stos-Gale 2000; Pańczyk et al. 2015) was used to deterime lead isotope ratios. Until know only Pańczyk et al. (2015) have published results of a provenance study on medieval silver coins from Poland. However, in this work a different statistical approach was used than in the present paper. What Pańczyk et al. did was collect a series of isotopic data for one artefact and then average them. In our study we propose a new innovative approach consisting of taking into account all the measurement results per one artefact and then their statistical calculation, chiefly with the use of linear discrimination models. This eliminates improper historical inference being a result of the average of the measurements' value. The lead isotope inhomogeneity of a given artefact is an effect of several factors: I. use of re-melted metal from other artefacts (e.g., dirhams: Eniosova and Mitoyan 20II; Eniosova 2009; Merkel 2016) II. use of several ores and/or one ore which may be characterised by isotopic inhomogeneity (see Fig. I); III. the use of lead from different places in the cupellation process (Merkel 2016). Therefore, one and the same artefact may display more than one lead isotope ratio value.

The origin of the silver which was in use in early medieval Poland is still largely unknown. There is literature and finds data that suggest the acquisition of ore from Germany (Harz Mountains), Czech and Slovak deposits, as well and Polish ores from the Dąbrowa Górnicza region (e.g., Rozmus and Bodnar 2004; Rozmus 20I4; 


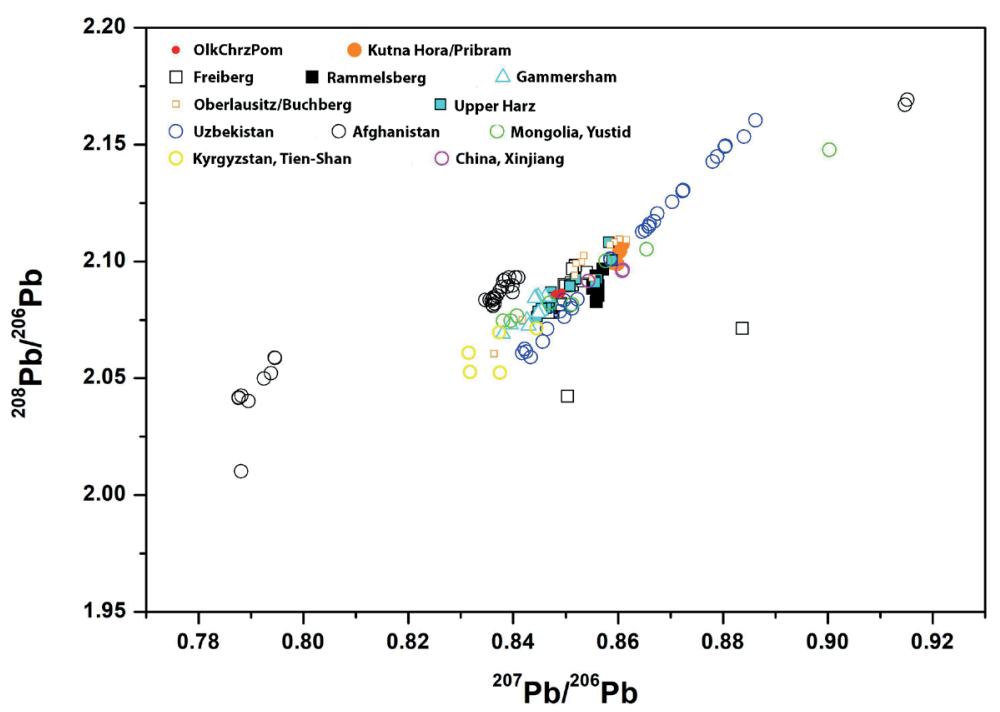

Fig. I. Literature lead isotope data of ores presented as $\mathrm{a}^{208} \mathrm{~Pb} /{ }^{206} \mathrm{~Pb}$ and ${ }^{207} \mathrm{~Pb} /{ }^{206} \mathrm{~Pb}$

Garbacz-Klempka and Rozmus 20I5; Merkel 2016). Furthermore, artefacts form the Middle East, especially dirhams, could have been used for re-melting (Merkel 2013, 20I6; Eniosova and Mitoyan 20II; Eniosova 2009). The composition of hoards and loose finds show that silver reached Poland in the Early Middle Ages in three phases. To the end of the Ioth century (Phase I) there is a prevalence of oriental silver, that is Arab dirhams (Bubnova 1963; Burâkov 1965, 1974; Dekówna 1971: 496-487; Cowell and Lowick 1988). In the second half of the Ioth century, Western European coins became more frequent in Poland. Then, the inflow of German coins prevails due to the discovery of silver deposits in the Harz region (Jammer 1952: 62; Suchodolski 1971: 22). The third phase is related to the period of rule of Bolesław Krzywousty (IIO7-II38) when raw silver dominates in hoards.

Generally, until now only basic issues concerning the attribution of silver artefacts (Kiersnowski 1960) are known. There is a direct relationship between coinage and authority in medieval Poland. Therefore, the study of such archaeological material must also take political issues into consideration (Suchodolski 1973; 20I2). In the light of research results, one of the most interesting types of coins are the cross deniers with peculiar thickened edges (Kędzierski 1998; Kędzierski et al. 20II). These have been regarded as silver coins until now.

An interesting phenomenon in early medieval Poland is the presence of raw silver ingots, so-called "cakes". These finds are considered to be specific only for Poland 
244 Ewelina A. Mista-Jakubowska, Renata Czech Btońska, Wtadystaw Duczko, Aneta M. Gójska ...

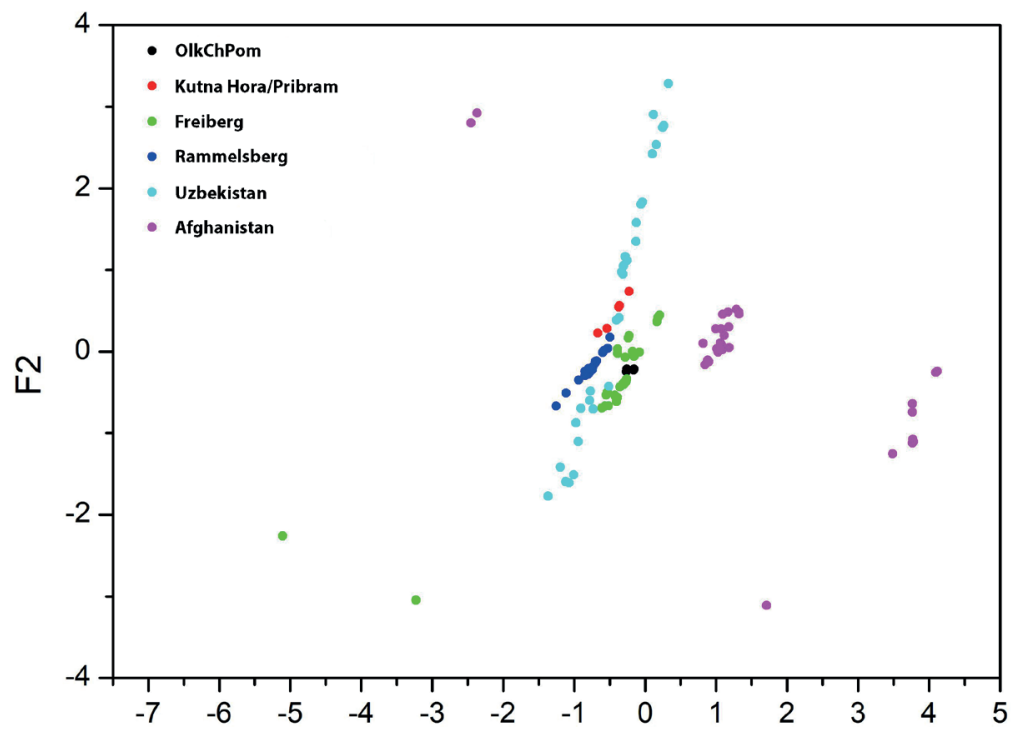

F1

Fig. 2. LDA results for selected ores group (2 parametrs: ${ }^{208} \mathrm{~Pb} /{ }^{206} \mathrm{~Pb} \mathrm{i}{ }^{207} \mathrm{~Pb} /{ }^{206} \mathrm{~Pb}, 6$ grups). These deposits are historically significant in the analysis of the provenance of European artefacts.

The data show a good separtaion by LDA model

(Rozmus and Tokaj 2009; Kędzierski 20II; Rozmus 20I4; Garbacz-Klempka and Rozmus 20I5; Kędzierski and Wyczółkowski 20I7). Such a type of silver artefacts are discovered in some Scandinavian hoards, especially from Swedish Scania and these are obviously of Polish origin. On the other hand, typical Scandinavian raw silver, represented by bars, often provided with so-called pecks, appears in Polish deposits (Duczko 2002). Both types of raw silver were studied during our project.

Jewellery is a separate issue. The large assemblage of material recovered mainly from silver hoards- one of the largest groups of this kind of material in Europe consists of female ornaments dominated by artefacts decorated with granulation and filigree (Duczko 1985). Typologically, they have late antique roots and they represent art developments within the former Roman province of Pannonia, reaching the highest level in the first Slav state of Great Moravia in the 9th century. After the fall of Moravia at the beginning of the Ioth century, its jewellers moved to the rising Czech state of the Premyslids and to the east, to Swedish Rus (Duczko 2018). Ornaments produced in eastern and especially in western workshops can be found in Polish hoards. Such ornaments also appear in Scandinavian hoards (Stenberger 1958; Duczko 1972; 1985). 


\section{METHODOLOGY}

The methodological approach is based on non- and micro-invasive techniques, which is a necessary trait in studies on archaeological finds.

Micro-invasive LA-ICP-MS allows the determination of lead isotope ratios in artefacts. Measurements were carried out using an ELAN 9000 Inductively Coupled Plasma Mass Spectrometer (Perkin Elmer SCIEX, Canada: www.perkinelmer.com) equipped with an LSX-200 laser ablation system (CETAX, USA: www.cetax.com). The LSX-200+ combines a stable environmentally selected $266 \mathrm{~nm}$ UV laser (Nd-YAG, solid state, Q-switches) with a high sampling efficiency, variable I to $20 \mathrm{~Hz}$ pulse repetition rate and maximum energy up to $6 \mathrm{~mJ} /$ pulse. A NIST 98I reference standard material was used for quantitative determination of lead isotope concentrations with a standard deviation $(S D)<0.1 \%$. For each artefact $n=40$ measurements were carried out with $\mathrm{SD}<3 \%$ in series. Such sampling provided information about silver inhomogeneity. All obtained data were statistically processed in such a manner.

Morphological changes of the artefacts' surface were registered by scanning electron microscopy (SEM) as secondary electron (SE) images. Then, the elemental composition of such selected micro-areas was determined by X-ray microanalysis (EDX) up to a $4 \mu \mathrm{m}$ depth for silver-copper alloy. For each micro-area at least $n=3$ measurements were carried out. Measurements were done using a Carl Zeiss EVO MAıo Scanning Electron Microscope equipped with an EDAX X-Flash Detector 5010 with a I23 eV spectra resolution (Zeiss Poland; www.zeiss.com) and provided with a Bruker Quantax 200 Esprit I.9 system for analyses of EDX spectra. The image analysis was carried out using a secondary electron detector (SE) with a resolution up to $2.0 \mathrm{~nm}$. Other parameters were the following: accelerating voltage $20 \mathrm{keV}$; measurement time: I2O s, $\mathrm{LLD}=0 . \mathrm{Iwt} \%$. The current and field magnification was adjusted to the type of morphology of each studied surface. Quantitative analysis was done using the non-pattern method with an error $<3 \%$ for main elements and $<20 \%$ for trace elements below $1 w t \%$.

The results of the elemental composition and lead isotope ratios obtained were processed using statistical methods, such as Linear Discriminant Analysis (LDA) and Principal Component Analysis (PCA). A supplementary method was Kernel Density Estimation (KDE) which allowed us to obtain a $3 \mathrm{D}$ model of lead isotopic ratio distribution in artefacts (e.g. Baxter 2003, 2016; Everitt and Hothorn 20II; see Fig. 3).

\section{RESULTS AND DISCUSSION}

\section{Assessing the provenance}

Fig. I offers a linear presentation of the results of lead isotope ratios for geological ores. ${ }^{208} \mathrm{~Pb} /{ }^{206} \mathrm{~Pb}$ and ${ }^{207} \mathrm{~Pb} /{ }^{206} \mathrm{~Pb}$ ratios were taken into consideration. The deposit isotope 
246 Ewelina A. Miśta-Jakubowska, Renata Czech Btońska, Wtadystaw Duczko, Aneta M. Gójska ...

data was mainly obtained from the literature (Hatz et al. 1991; Chiaradia et al. 2006; Pavlova and Borisienko 2009; Merkel et al. 2013; Ettler et al. 2015; Merkel 2016). These authors used an invasive mass spectrometry technique which produced averaged results in the sampling stage. Samples from Pomorzany and Olkusz mines were examined in the course of the project. Moreover, a sample from Dąbrowa Górnicza-Łosień (Rozmus 20I4) was also analysed. In this case, the results are similar to those for the Pomorzany and Olkusz project samples, but are significantly at variance with the trend shown in Fig. I. Therefore, only the data from the literature data eventually used in our provenance study. What is important, until now there is still a lack of an adequate data base (like OXALID: http://oxalid.arch.ox.ac.uk/, access on 25 April 2019) containing isotopic data for deposits which are important for the circulation of silver in the discussed period. Bearing this in mind, our provenance study based on available literature data has a pioneering character. Further provenance studies should be successively extended in relation to new available data and it is a matter of utmost importance to set up a freely available lead isotope data base.

Fig. 2 offers LDA (Kulczycki 2005; Šmit and Šemrov 2006) lead isotope ratio distribution for the discussed ores. Both Figs. I and 2 demonstate that there is a significant overlap in isotopic values for various ore deposits.

Fig. I. shows that taking into account all literature data in a study of provenance of silver artefacts may be a source of confusion in further provenance studies This is due to the fact that isotopic "fingerprints" for deposits from different regions are similar or overlap. According to the results of the LDA analysis, group allocation, i.e., a relatively good isotopic separation is shown by deposits from Rammelsberg (85\%), Uzbekistan (53\%), Afghanistan (91\%), Kyrgyzstan (80\%) and China (67\%). The largest degree of isotopic heterogeneity is exhibited by deposits from the areas of Freiberg, Oberlausitz, Upper Harz and Mongolia. Therefore, in further provenance investigation, only ore groups presented in Fig.2 as a LDA transformation were used.

As regards the LDA separation data presented in Fig. 2, the LDA allocation in groups in Fig. 2 is better after the removal of three strongly overlapping sets of data (Gammersham, Oberlausitz/Buchberg and Upper Harz) and ores from China, Mongolia and Kyrgyzstan which was used only to provenance study of dirhams. Namely, after the selection, the OlkChrzPom deposits shows an improvement from 40 to $100 \%$, Kutna Hora/Pribram from 20 to $40 \%$, Freiberg from 31 to $35 \%$, and Rammelsberg from 85 to $96 \%$. There is no change for Uzbekistan ( $53 \%$ ), while the classification for Afghanistan improves from 9I to 94\%. Only in the case of the Polish deposits (OlkChrzPom), Rammelsberg and Afghanistan, is the separation satisfactory. The deposit from Freiberg is the least homogeneous. Therefore, any provenancing classifications to this deposit are to be treated with care. The same applies to the Kutna Hora deposit.

Figs. 3 and 4 offer examples of the results obtained during the study on detailed isotopic variation in artefacts. An example of the lead isotope ratio distribution 
including all $\mathrm{n}=40$ measurements in one artefact can be seen in Fig. 3. Similar inhomogeneous isotope distributions were observed in all studied finds and this fact is connected with the possibility of use of different substrates and processes in silver production described in the introduction to this paper.

Due to the inhomogeneous lead isotope characteristics of the silver artefacts it is necessary to use statistical tools to interpret these results. Two approaches can be proposed. In the first one, the most probable value can be applied as a lead isotope ratio indicator. For example, in Fig. 3:b for ${ }^{204} \mathrm{~Pb} /{ }^{206} \mathrm{~Pb}$ it is the maximum value of 0.054 with error FWHM=0.003, while for ${ }^{208} \mathrm{~Pb} /{ }^{206} \mathrm{~Pb}$ it is the maximum value of 2.083 with error=0.2II. This approach allows us to obtain one measurement value per artefact with an error corresponding to the FWHM for a series of n-measurements, as it can be seen in Fig. 3. Unfortunately, this does not take lack of homogeneity of alloys into consideration (see peaks with lower intensity in Fig. 3:b), and this inhomogeneity may be a result of the use of various sources and deposits. Besides, as it can be seen in Fig. 4, the coins alloy demonstrates (as it was the case with the deposits), a significant degree of lead isotope ratio overlapping.

Therefore, it seems appropriate to include into the calculation all measurement results obtained for one artefact. Then, the LDA analysis can classify this data to deposit values. In this way, we do not lose information about the possibility of use of several deposits and sources in the manufacturing process of artefacts by means of re-melting. In addition, we also take into consideration the isotope inhomogeneity of the ore deposits, which is shown in Figs. I and 2.

Tab. I presents LDA provenance study results obtained for Polish and Saxon coins, raw silver (cakes) and jewellery. The LDA analysis of the detailed isotopic variability in the group of Polish and Saxon coins seems to imply that they are made from metal coming from the same source (see Tab. I). Furthermore, it is not possible to separate subgroups of silver sources in coin types which originate from these countries.

As can be seen in Tab.I, the dirhams from Northern Afghanistan (from the Andaraba and Ma'din mints) and dirhams from mints in Uzbekistan (the Ašršas mint) fit very well within the deposit data available in literature (Merkel et al. 2013). A significant part of coin and jewellery silver is constituted by Central Asian bullion. On the other hand, the silver in these artefacts was also smelted from German (Fr, Ram) and Polish ores (OCP). In the coins and jewellery the share of the Czech ores (KHP) is slight which is in contrast to the raw silver. Cakes are mainly made of silver from Czech (25\%) and Polish (33\%) deposits, which is consistent with their identification as local semi-finished products (Rozmus 20I4; Garbacz-Klempka and Rozmus 2015). However, they were not semi-products for the manufacture of the artefacts studied in the course of this project. 
248 Ewelina A. Miśta-Jakubowska, Renata Czech Btońska, Wtadystaw Duczko, Aneta M. Gójska ...

a)

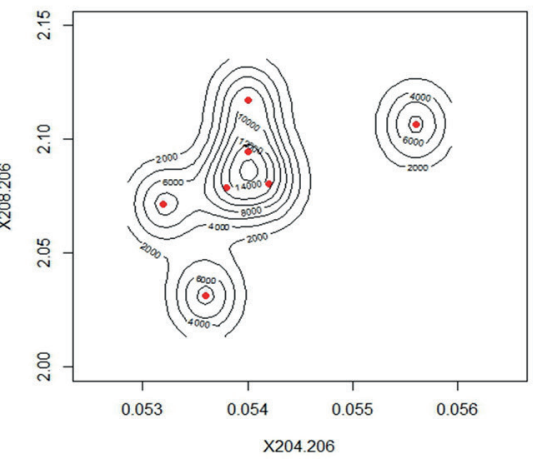

b)

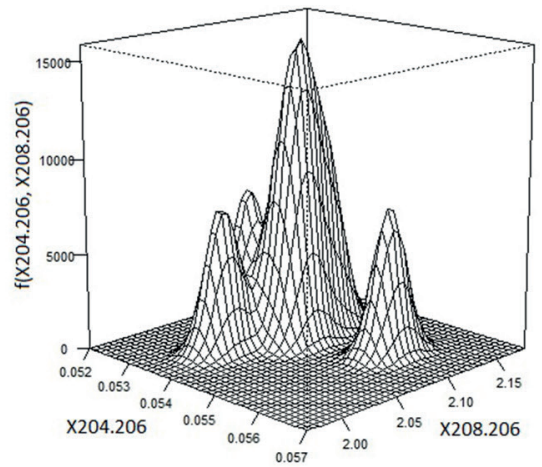

Fig. 3. Jewellery from the Zakrzew hoard. a) KDE contour plot; b) KDE 3 d surface plot with the maximum value and error (full width at half maximum or (FWHM) of the peak) for the lead isotope ratios (X204.206, $\mathrm{X}_{208.206)}$ obtained for all measurements.

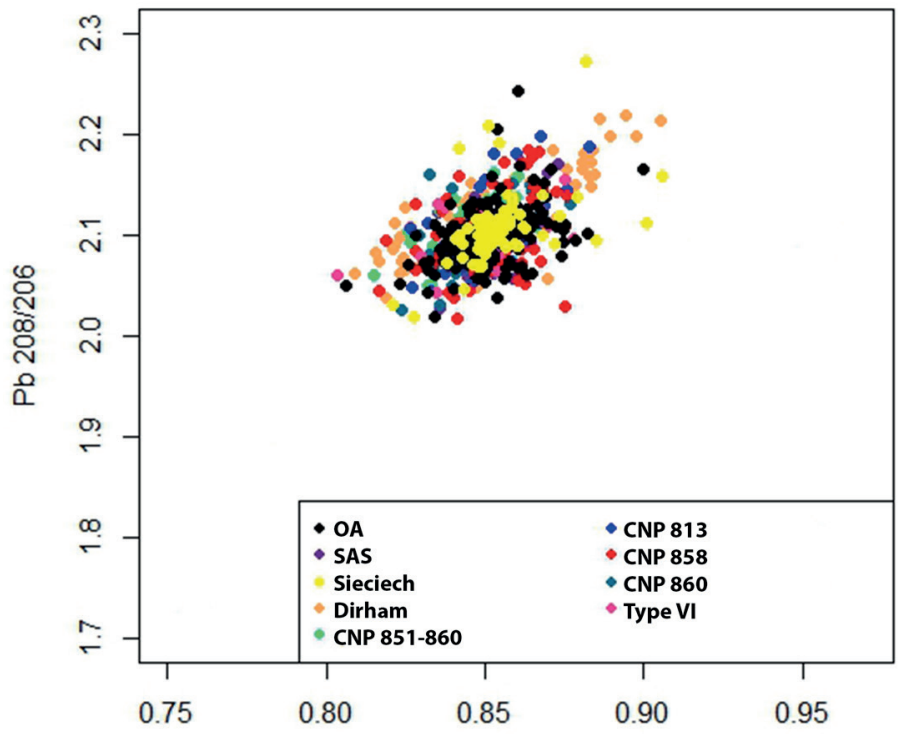

$\mathrm{Pb} 207 / 206$

Fig. 4. Lead isotope ratio results presented as a $2 \mathrm{~d} \mathrm{~Pb}^{207} / \mathrm{Pb}^{206}$ and $\mathrm{Pb} / 208 / \mathrm{Pb}^{206}$ diagram. Results for coins showing the most probable value for one artefact.

OA - Otto and Adelaide deniers, SAS - Saxon cross deniers, CNP - Polish cross deniers. 
Table I. Correlation matrix (LDA) for a set of artefacts and deposit data. Explanations: "no match" - no reliable allocation for the deposit group, lack of lead isotope data; the geological ores:

KPH - Kutna Hora and Pribram; Fr - Freiberg, Ram - Rammelsberg, OCP - Olkusz Chrzanów

Pomorzany, U - Uzbekistan, A - Afghanistan, M - Mongolia, K - Kyrgyzstan, Ch - China.

\begin{tabular}{|l|c|c|c|c|c|c|c|c|c|c|}
\hline (\%) & $\begin{array}{c}\text { no } \\
\text { match }\end{array}$ & KHP & Fr & Ram & OCP & U & A & M & K & Ch \\
\hline Saxon coins & I7 & I & I3 & I2 & 9 & 26 & 22 & - & - & \\
\hline Polish coins & I8 & I & IO & I2 & I0 & 27 & 22 & - & - & \\
\hline $\begin{array}{l}\text { Raw silver } \\
\text { (cakes) }\end{array}$ & 33 & 25 & I & 8 & 33 & - & - & - & - & \\
\hline Jewelleries & I9 & 2 & II & I2 & 8 & 25 & 24 & - & - & - \\
\hline $\begin{array}{l}\text { Dirhams } \\
\text { (from N. Afgh.) }\end{array}$ & 40 & - & - & - & - & 6 & 29 & 5 & I6 & 4 \\
\hline $\begin{array}{l}\text { Dirhams } \\
\text { (from Uzb.) }\end{array}$ & 79 & - & - & - & - & I6 & 2 & - & - & 3 \\
\hline
\end{tabular}

\section{Elemental composition analysis}

During the elemental composition study of the coins, the following types could be distinguished: (i) coins from Asia (dirhams) with significant contents of lead up to $20 \%$ wt and bismuth up to I0\%wt in micro-areas, (ii) typical coins with the main alloy components: silver up to $80 \% \mathrm{wt}$ and copper up to $5 \% \mathrm{wt}$, and (iii) coins with element concentration anomalies on the surface that are characterised by an enrichment of copper and zinc in the coin core. This occurs in the case of cross deniers with thickened edges. Fig. 5 offers a distribution of the main elements in individual coin groups.

The results obtained during the present project are similar to those reported by Hensel for finds from the Ostrów Lednicki hoard (Hensel 2013). As can be seen in Figs. 5 and. 6, Otto and Adelaide deniers (OA) and dirhams show copper enrichment while Polish cross deniers demonstrate a higher content of zinc in the surface. This phenomenon is related to technological aspects of minting of cross deniers (Miśta and Gójska 20I5; Miśta et al. 2016). Namely, corrosion loss was observed for some variants of cross deniers (CNP 813, 858 and 860) in the SEM-SE image. In these micro-areas a higher content of copper and zinc was observed. This indicates that that Polish cross deniers and also Palatine Sieciech's coins (as reported Kędzierski 1998) may have copper-based cores with addition of zinc. 
250 Ewelina A. Mista-Jakubowska, Renata Czech Btonska, Wtadystaw Duczko, Aneta M. Gójska ...

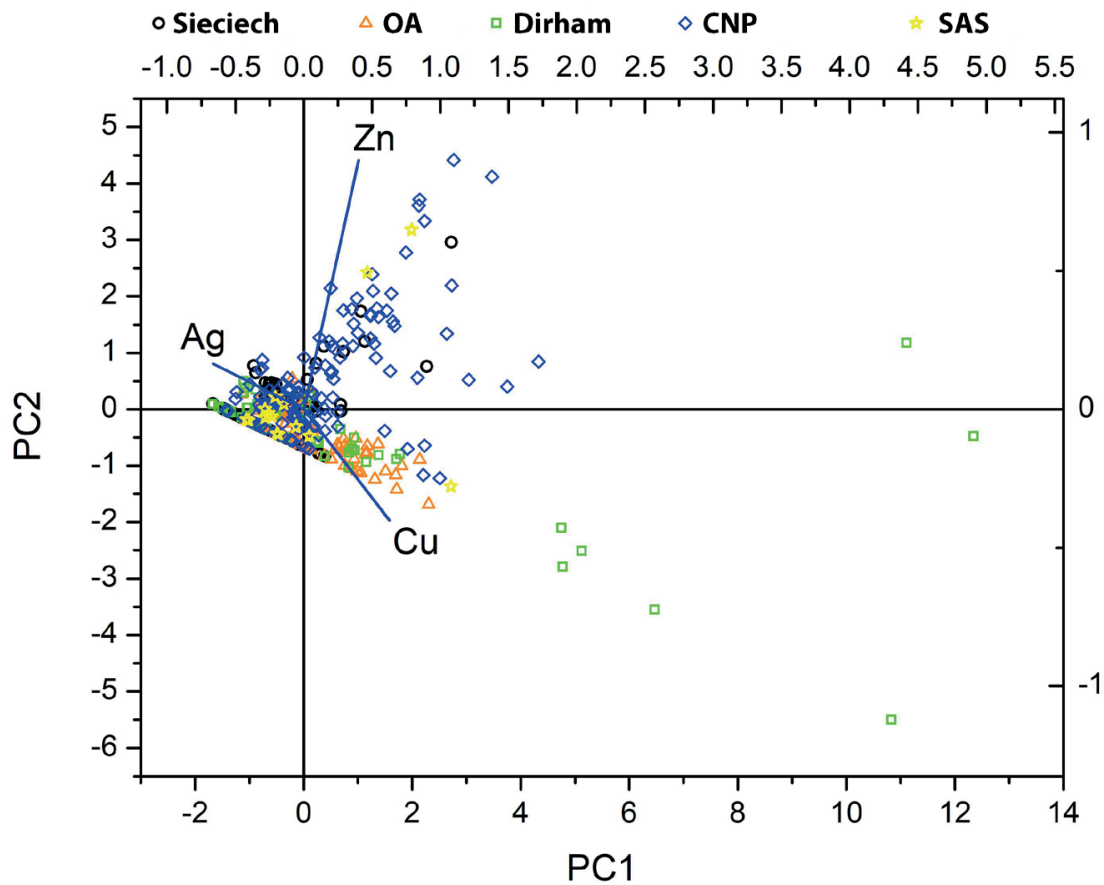

Fig. 5. PCA (correlation) results for silver, copper and zinc concentrations in different type of coins.

Fig. 6 presents the main elements' distribution in the silver alloy of different types of artefacts. Silver $(\mathrm{Ag})$, copper $(\mathrm{Cu})$, lead $(\mathrm{Pb})$ and zinc $(\mathrm{Zn})$ concentrations (wt\% norm.) were taken into account in the studied types of artefacts.

For raw silver, we observed elemental concentration anomalies for the cakes. The SEM-EDX results show that the surface of some artefacts from this group is enriched in lead. There are micro-areas with a lead content up to ca. $67 \mathrm{wt} \%$. In the cross-sections of these artefacts, the lead content is ca. $6 \mathrm{wt} \%$, which is considerably higher than in the case of the coins and jewellery under study. This fact can suggest that lead surface enrichment in the form of oxides represents the remnants of an unfinished process of silver extraction from galena deposits (Garbacz-Klempka and Rozmus 20I5). Moreover, the alloy of the cakes lacks a copper addition which also indicates that these were semi-finished products for the smelting of pure silver (Ashkenazi et al. 20I7; GarbaczKlempka and Rozmus 2015). As can be seen in Fig. 6, the bars are characterised by a different alloy with higher contents of zinc and copper.

During the SEM-EDX study of the jewellery, two technological areas were selected - the base alloy exposed on the surface, as well as areas of granulation and soldering. 


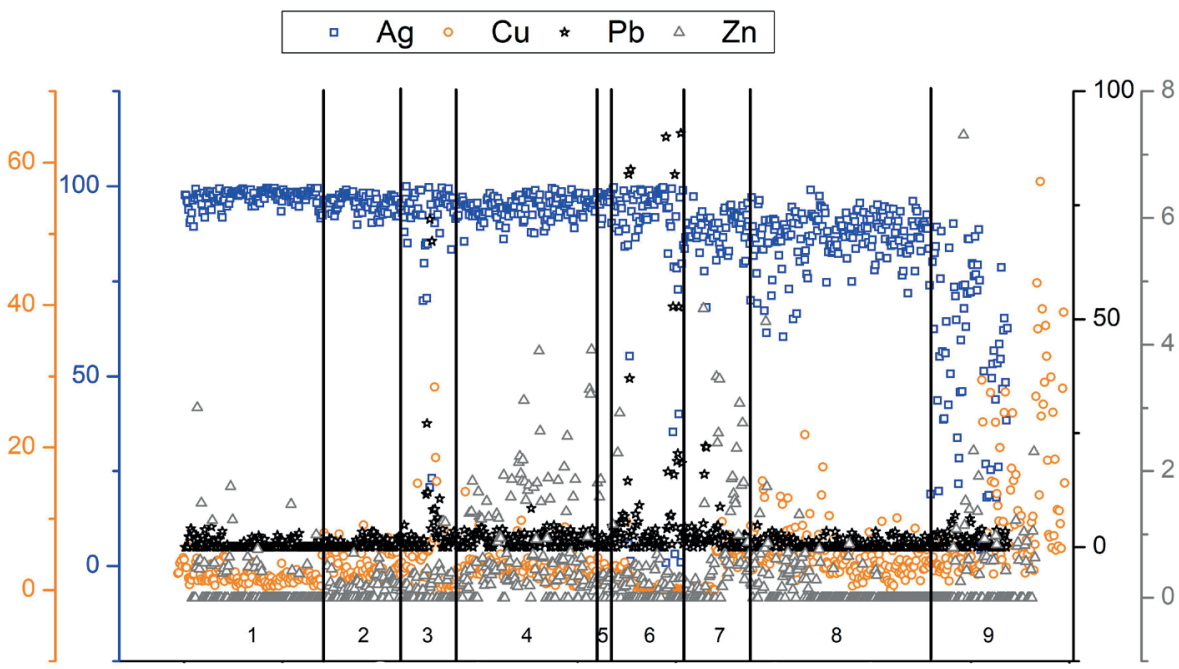

1.Sieciech 2.OA 3. Dirham 4. CNP 5.SAS 6. Cakes 7. Bars 8. Jewelry Base Alloy 9. Jewelry Solder

Fig. 6. Silver $(\mathrm{Ag})$, copper $(\mathrm{Cu})$, lead $(\mathrm{Pb})$ and zinc $(\mathrm{Zn})$ concentrations (wt\% norm.) in the studied types of artefacts.

The latter has a different elemental composition, which is related to technological aspects. The soldering region shows copper enrichment related to a higher oxygen content and sometimes to the presence of low-melting elements such as antimony $\mathrm{Sb})$. The high oxygen content indicates the use of thermal treatment in the soldering process while the copper content in the solder may indicate the use of chemical bonding, such as the chrysocolla process (Duczko 1985; Demortier et al. 1999; Ashkenazi et al. 2017; Miśta-Jakubowska et al. 2019).

\section{CONCLUSIONS}

The present study on silver artefacts provides some clues for understanding silver circulation in early medieval Poland. A detailed analysis in terms of elemental compositions is a very difficult task. This is primarily due to the lack of homogeneity of the alloys and geological ores and also to a different production technology of each type of silver artefacts: jewellery, coins and raw silver ingots. The data collected during the project is still undergoing statistical processing. Since the analysed finds were produced by a series of anthropogenic actions (extraction of raw metal, recycling, 
252 Ewelina A. Miśta-Jakubowska, Renata Czech Btońska, Wtadystaw Duczko, Aneta M. Gójska ...

alloying with other metal) their structures are heterogeneous in the micro-scale. Thus, the obtained average elemental composition may be burdened with uncertainty (Liu et al. 2018). Therefore, the results should be analysed using advanced statistical methods without averaging results.

On the other hand, it can be said that some key information has been obtained during the research. The Polish and Saxon coins are made from the same silver source, which was based mainly on ores mined in Afghanistan, Uzbekistan and Germany. Furthermore, copper-based cores covered with silver sheets were discovered in the cross deniers. The same technology may have been used in the minting of Palatine Sieciech's deniers (Kędzierski 1998). Concerning their elemental and isotopic composition, North Afghanistan dirhams from Ma'din and Andaraba mints are similar. As is reported in the literature, ores from Panjhìr Valley were used in their manufacture (Cowell and Lowick 1988). All dirhams are characterised by higher content of copper, bismuth and lead in micro-areas of the surface. This indicates a low degree of mixing and admixture extraction. Furthermore, mainly Central Asian silver was used in the manufacture of the jewellery, as it has been reported by other scholars (Eniosova 2009; Eniosova and Mitoyan 20II; Merkel 20I6). This metal may also have come from re-melted dirhams. A significant contribution was also made by Germany deposits located in Freiberg and Rammelsberg. The elemental composition and surface morphology study allowed to conclude that the ornamentation on the surface of the jewellery was made with the use of chemical soldering (Duczko 1985; Miśta-Jakubowska et al. 2019). The cakes called raw silver are characterised by different isotopic and elemental composition than the other artefacts studied. The results confirm the supposition that these are local semi-finished products, final products of extraction and the cupellation process from the ores. They lack copper admixture with a higher content of lead and their isotopic composition corresponds to Polish and Czech ores.

\section{ACKNOWLEDGEMENTS}

The project "Study on origin and circulation of silver in early medieval Poland by lead isotope ratio analysis" was carried out within the framework of the NCN OPUS grant (UMO-2013/09/B/HS3/03289), leader dr hab. Wladyslaw Duczko. The project was realizing in cooperation with Adam Kędzierski, Dariusz Wyczółkowski, Jarosław Gaca, Olga Gaca and Stanisław Mikulski. 


\section{REFERENCES:}

Ashkenazi, D., Gitler H., Stern, A. and Tal, O. 2017. Metallurgical investigation on fourth century BCE silver jewellery of two hoards from Samaria. Scientific Reports: I-I4. doi: I0.I038/srep40659.

Baxter, J. M. 2003. Statistics in archaeology. London.

Baxter, M. 20I6. Multivariate Analysis of Archaeometric Data: An Introduction. Springer.

Bubnova, M. A. 1963. Dobyča serebro-svincovych rud v Šel'dži v IX-XII vv. Arheologičeskie pamâtniki Tallaskoj doliny: 225-262.

Burâkov, Ǔ. F. 1965. Drevnij serebrânnyj rudnik Laškerek. Sovetskẩ Arheologiâ r: 282-289.

Burâkov, Ǔ. F. 1974. Gornoe delo I metallurgiâ srednevekogo Ilaka V-nacala XIII v. Moskva.

Chiaradia, M., Konopelko, D., Seltmann, R. and Cliff, R. A. 2006. Lead isotope variations across terrane boundaries of the Tien Shan and Chinese Altaj. Miner Deposita 4I: 422-429.

Cowell, M. R. and Lowick, N. M. 1988. Silver from the Panjhír mines. In W. A. Oddy (ed.), Metallurgy in Numismatics, Vol.2. Londyn.

Dekówna, M. 1971. Stan badań nad górnictwem srebra i tzw. kryzysem srebra w Azji Środkowej. Archeologia Polski I6: 483-50I.

Demortier, G., Fernandez-Gomez, F., Ontalba Salamanca M. A. and Coquay P. 1999. PIXE in an external microbeam arrangement for the study of finely decorated tartesic gold jewellery items. Nuclear Instruments and Methods in Physics. Research B 158: 275-280.

Duczko, W. 1972. Slavic silver jewellery from the Viking Period. An analysis of material from Gotland. Unpublished C-uppsats i arkeologi. Uppsala.

Duczko, W. 1985. Birka V. The filigree and granulation work $p$ the Viking Period. An analysis of the material from Björkö. Uppsala.

Duczko, W. 2002. Test or Magic? Pecks on Viking-Age Silver. In R. Kiersnowski, S. K. Kuczyński, M. Męclewska, M. Mielczarek and B. Paszkiewicz (eds), Moneta mediaevalis, Studia numizmatyczne $i$ historyczne ofiarowane Profesorowi Stanistawowi Suchodolskiemu w 65 rocznice urodzin, 192-208. Warsaw.

Duczko, W. 20I8. Post-wielkomorawski fenomen. Wczesnośredniowieczna sztuka złotnicza w Środkowej i Wschodniej Europie (Post-Great Moravian Phenomenon. Early Medieval Goldsmithery in Middle and Eastern Europe). In B. Gediga, A. Grossman and W. Piotrowski (eds), Inspiracje i funkcje sztuki pradziejowej i wczesnośredniowiecznej, I07-I19. Biskupin-Wrocław.

Dziunikowski, B. 1998. Zastosowania izotopów promieniotwórczych, Część II. Kraków.

Eniosova, N. and Mitoyan, R. 2oII. Arabic Coins as a Silver Source for Slavonic and Scandinavian Jewellers in the Tenth Century AD. In I. Turbanti-Memmi (ed.), Proceedings of the 37 th International Symposium on Archaeometry, 597-584. Berlin.

Eniosova, N. V. 2009. Tracing the routes of silver procurement to the early urban centre Gnëzdovo in the Ioth/early itth centuries. In T. Bendeguz (ed.), Die Archäolodie der Frühen Ungarn Chronologie, Technologie und Methodik, 26I-283. Budapest.

Ettler, V., Johan, Z., Zavřel, J., Wallisová, M. S., Mihlajevič, M. and Šebek, O. 20I5. Slag remains from the Na Slupi site (Prague, Czech Republic): evidence for early medieval non-ferrous metal smelting. Journal of Archaeological Sciences 53: 72-83.

Everitt, B. S. and Hothorn, T. 20II. An Introduction to Applied Multivariate Analysis. Springer Science+ Business Media.

Gale, N. H. and Stos-Gale Z. A. 200o. Lead isotope analyses applied to provenance studies. In E. Ciliberto and G. Spoto (eds), Modern analytical methods in art and Archaeology, 503-584. New York.

Garbacz-Klempka, A. and Rozmus, D. 2015. The "Metallurgist's Hoard. Silver and Lead Smelting in the Early Medieval Poland. Archives of Foundary Engineering 15: 17-20. 
254 Ewelina A. Miśta-Jakubowska, Renata Czech Btońska, Wtadystaw Duczko, Aneta M. Gójska ...

Hatz, G., Hatz, V., Zwicker, U., Gale, N. and Gale, Z. 1991. Otto-Adelheid-Pfennige. Commentationes de Nummis Saeculorum IX-XII. In Suecia Repertis. Nova Series 7, The Royal Swedish Academy of Letters History and Antiquities.

Hensel, Z. 20I3. Analizy metaloznawcze monet i biżuterii z Muzeum Pierwszych Piastów na Lednicy. In A. Tabaka and A. M. Wyrwa (eds), Coins and jewellery from Ostrow Lednicki and its vicinity, I43 - I72. Lednica.

Jammer, V. 1952. Die Anfänge der Münzprägung im Herzogtum Sachsen. Hamburg.

Kędzierski, A. 1998. Polskie denary krzyżowe ze skarbu ze Słuszkowa. Wiadomości Numizmatyczne XLII: I-2.

Kędzierski, A. and Wyczółkowski, D. 20I7. Skarb placków srebrnych z Kalisza Dobrzeca. Nowe możliwości badawcze problemu srebra lanego. In M. Bogucki, W. Garbaczewski and G. Snieżko (eds), Nummi et Humanitas, studia ofiarowane profesorowi Stanistawowi Suchodolskiemu $w 80$ rocznice urodzin, 333-350. Warsaw.

Kędzierski, A., Ziąbka, L. and Miłek, S. 2oII. Skarb placków srebrnych z Kalisza-Dobrzeca. Informacja wstępna. Rocznik Kaliski XXXVIII: 219-222.

Kiersnowski, R. 1960. Pieniądz kruszcowy w Polsce wczesnośredniowiecznej. Warsaw.

Kulczycki, P. 2005. Estymatory jądrowe w analizie systemowej. Warsaw.

Liu, S. R., Chen, K. L., Rehren, Th., Mei, J. J., Chen, J. L., Liu, Y. and Killick, D. 20I8. Lead isotope and metal source of Shang bronzes: A response to Sun et al.'s comments. Archaeometry (in print: doi IO.IIII/arcm.I24II).

Merkel, S. 20I3. Analysis of Slag, Ore and Silver from the Tashkent and Samarkand Areas: Medieval Silver Production and the Coinage of Samanid Central Asia. Archäometrieund Denkmalpflege. Metalla Sonderheft 6: 62-66.

Merkel, S., Brautigam, B., Klein, S. and Hauptmann, A. 20I3. The Analysis of Slag from the Panjhir Mining Region, Afghanistan: An Investigation of (Medieval) Silver Production Technology. Archäologische Mitteilungen aus Iran und Turan 45: 23I-249.

Merkel, S. W. 2016. Silver and the Silver Economy at Hedeby. Bochum.

Miśta-Jakubowska, E., Czech Błońska, R., Duczko, W., Gójska, A., Kalbarczyk, P., Żabiński, G. and Trela, K. 2019. Archaeometric studies on early medieval silver jewellery from Central and Eastern Europe. Archaeological and Anthropological Science. doi: 10.1007/sI2520-019-00935-z.

Miśta, E. and Gójska, A. 20I5. W poszukiwaniu źródeł srebrnego kruszcu we wczesnośredniowiecznej Polsce. Warszawski Pamiętnik Numizmatyczny 4.

Miśta, E., Gójska, A. and Kalbarczyk, P. 20I6. Badania proweniencyjne i technologiczne obiektów archeologicznych wykonanych ze stopów srebra i miedzi. In T. Łojewski (ed.), Nauki Sciste i zabytki, post-conference material from 25.09.20I5, 9I. Kraków.

Pańczyk, E., Sartowska, B., Waliś, L., Dudek, J., Weker,W. and Widawski, M. 2015. The origin and chronology of medieval silver coins based on the analysis of chemical composition. Nukleonika 6o(3): 657-663.

Pavlova, G. G. and Borisenko, A. S. 2009. The age of Ag-Sb deposits of Central Asia and their correlation with other types of ores systems and magnetism. Ore Geology Reviews 35: 165-185.

Rozmus, D. 20I4. Wczesnośredniowieczne zagtębie hutnictwa srebra i otowiu na obszarach obecnego pogranicza Ślaska i Matopolski (2 potowa XI-XIIXIII wiek). Kraków.

Rozmus, D. and Bodnar, R. 2004. Badania archeologiczne na wielokulturowym stanowisku 8 w Dąbrowie Górniczej-Łośniu, województwo śląskie. In Badania archeologiczne na Górnym Śląsu i ziemiach pogranicznych w latach 200I-2002, I46-I55. Katowice.

Rozmus, D. and Tokaj, J. 2009. Wstępne wyniki badań nad „Skarbem Hutnika” - problematyka srebrnych placków. In D. Rozmus and S. Witkowski (eds), Gospodarka nad Przemszq i Krynica od pradziejów 
do początków XX w. w świetle badań interdyscyplinarnych, IO4-II5. Dąbrowa-Górnicza-OlkuszSosnowiec.

Šmit, $\check{Z}$. and Šemrov, A. 2006. Early medieval coinage in the territory of Slovenia. Nuclear Instruments and Methods in Physics Research B 252: 290-298.

Stenberger, M. 1958. Die Schatsfunde Gotlands der Wikingerzeit 3. Stockholm.

Suchodolski, S. I971. Początki mennictwa w Europie Środkowej, Wschodniej i Pótnocnej. Wrocław.

Suchodolski, S. 1973. Mennictwo polskie w XI i XII wieku. Wroclaw.

Suchodolski, S. 20I2. Pierwsza fala monet zachodnioeuropejskich w X w. na Mazowszu i w Polsce Środkowej. In K. Pietaszek-Cholewa (ed.), Numizmatyka średniowieczna, I53-160. Warszawa. 
